\title{
Hyperspectral response of cape gooseberry (Physalis peruviana L.) plants inoculated with Fusarium oxysporum f. sp. physali for vascular wilt detection
}

\section{Respuesta hiperespectral de plantas de uchuva (Physalis peruviana L.), inoculadas con Fusarium oxysporum f. sp. physali, para la detección del marchitamiento vascular}
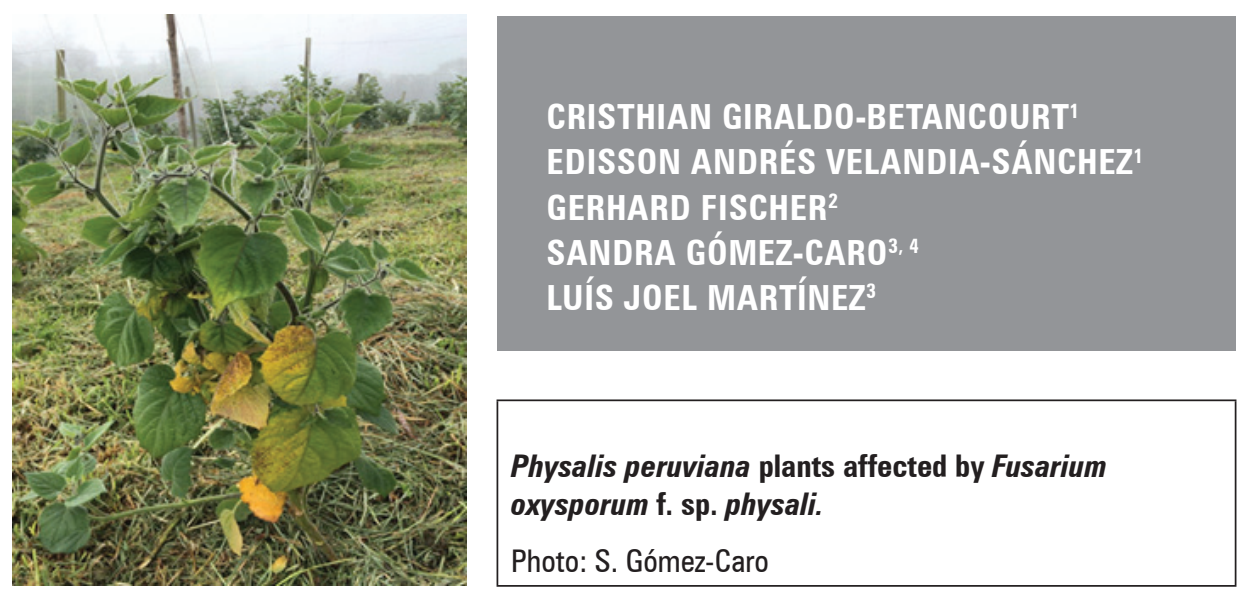

\section{Physalis peruviana plants affected by Fusarium oxysporum f. sp. physali.}

Photo: S. Gómez-Caro

\begin{abstract}
This study used greenhouse conditions to determine the hyperspectral responses of cape gooseberry (Physalis peruviana L.) plants inoculated with different Fusarium oxysporum f. sp. physali densities because the causal agent of vascular wilt generates great economic losses for farmers. A completely randomized design with four replicates was established. The evaluated treatments were inoculum densities $0.0,1.0 \cdot 10^{3}$ and $1.0 \cdot 10^{6}$ conidia/mL of the pathogen. The inoculation was done with immersion of roots in conidia suspensions. The spectral response was directly measured on the plant leaves with a spectroradiometer. Non-invasive detection in the P. peruviana - F. oxysporum pathosystem with reflectance values was used with different spectral indices related to the visible and Red Edge, which were calculated and correlated with the disease variables. The treatments showed significant differences in the visible spectrum starting 14 days after inoculation with higher reflectance values. The chlorophyll index at the red edge (ChRE), the modified chlorophyll absorption index (MCARI), the simple ratio index (SR) and the Zarco \& Miller index (ZM) showed highly significant correlations with the area under the disease progress curve for leaves (AUDPCL), leaf area and fresh weight

1 Universidad Nacional de Colombia, Faculty of Agricultural Sciences, Program in Geomatics, Bogota (Colombia). ORCID Giraldo-Betancourt, C.: 0000-0002-6917-4979; ORCID Velandia-Sánchez, E.A.: 0000-0002-4324-043X

2 Independent consulter, Emeritus researcher of Colciencias, Bogota (Colombia). ORCID Fischer, G.: 0000-0001-8101-0507

3 Universidad Nacional de Colombia, Faculty of Agricultural Sciences, Bogota (Colombia). ORCID Gómez-Caro, S.: 0000-0002-6670-0275; ORCID Martínez, L.J.: 0000-0001-9010-9189

4 Corresponding author.sgomezc@unal.edu.co
\end{abstract}


of the aerial part of the plants. This study showed the potential of spectral patterns for the detection and study of Fusarium wilt in P. peruviana.

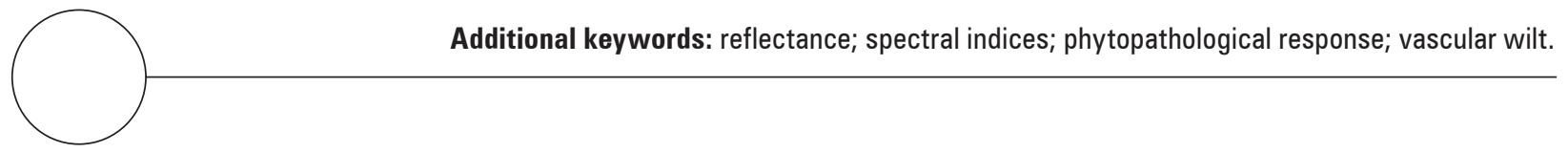

\section{RESUMEN}

El objetivo de este estudio fue determinar en condiciones de invernadero la respuesta hiperespectral de las plantas de uchuva (Physalis peruviana L.), inoculadas con diferentes densidades de Fusarium oxysporum f. sp. physali, agente causal del marchitamiento vascular que genera grandes pérdidas económicas para los agricultores. Se estableció un diseño completamente al azar con cuatro repeticiones. Los tratamientos evaluados fueron densidades de inóculo $0.0,1.0 \cdot 10^{3}$ y $1.0 \cdot 10^{6}$ conidios $/ \mathrm{mL}$ del patógeno. La inoculación se realizó por inmersión de raíces en la suspensión de conidios. Para la evaluación de la respuesta espectral, se usó un espectroradiómetro midiendo directamente las hojas de la planta. Para la detección no invasiva en el patosistema P. peruviana - F. oxysporum, con los valores de reflectancia se calcularon diferentes índices espectrales relacionados con el Red Edge y se correlacionaron con las variables de la enfermedad. Los tratamientos mostraron diferencias significativas en el espectro visible a partir de 14 días después de la inoculación con los mayores valores de reflectancia. El índice de clorofila en el Red Edge (ChRE), el índice de absorción de clorofila modificado (MCARI), el índice de relación simple (SR) y el índice de Zarco and Miller (ZM) mostraron correlaciones altamente significativas con el área bajo de la curva del progreso de la enfermedad (AUDPCL), el peso fresco de la parte aérea de la planta y el área foliar. El estudio mostró el potencial de las respuestas espectrales para la detección y el estudio del marchitamiento vascular por Fusarium en P. peruviana.

Palabras clave adicionales: reflectancia; índices espectrales; respuesta fitopatológica; marchitez vascular.

Received for publication: 29-04-2020 Accepted for publication: 23-11-2020

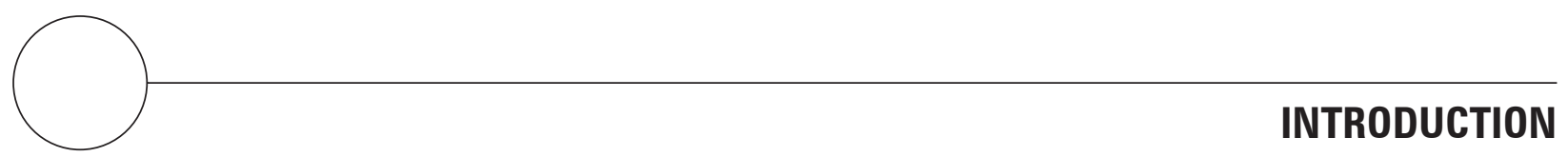

The cultivation of cape gooseberry (Physalis peruviana L.) is of great economic importance for Colombia since this species is the third most exported fruit, with a production of $16,109 \mathrm{t}$ on 1,312 ha in 2018 (Agronet, 2020). This fruit is desirable because of its nutritional and medicinal characteristics, which make it an exotic fruit (Fischer and Melgarejo, 2020). Although most cape gooseberry crops belong to small farmers, export companies have decided to plant their own crops to obtain constant production to meet the market demands of this fruit (Fischer et al., 2014).

Fusarium oxysporum is the causal agent of vascular wilt in plants, and, in cape gooseberries, the incidence of this disease, caused by F. oxysporum f. sp. physali (Simbaqueba et al., 2018), generates great economic losses for farmers. Therefore, new pathogen-free areas are required (Villarreal-Navarrete et al., 2017). In 2014, F. oxysporum caused the greatest amount of economic damage to several agricultural crops when compared to other plant pathogens because of its large spatial distribution in Europe, the Middle East, North Africa (Shabani et al., 2014), the United States, Canada, Australia, Thailand, China, Colombia, Ecuador, Costa Rica, Panama, Brazil, Peru, and Argentina, especially in banana (Musa acuminata), tomato (Solanum lycopersicum) (McGovern, 2015), onion (Allium cepa) (Southwood et al., 2015) and ornamental crops (Gullino et al., 2015; Lecomte et al., 2016).

In Colombia, the planted area for cape gooseberry was 1,087 ha by 2009 , with a yield of $17.78 \mathrm{t} \mathrm{ha}^{-1}$; however, in 2010, there was a decrease of 342.1 ha (Agronet, 2020) because of inadequate crop management, which generated a greater incidence and severity of vascular wilt caused by $F$. oxysporum f. sp. physali. F. oxysporum can survive up to 30 years under adverse conditions because of its particular survival 
structures known as chlamydospores. These structures germinate when in contact with the roots of plants, generating an appressorium that penetrates root cells and develops mycelium that reaches the vascular system (Cruz et al., 2012; Sharma et al., 2018; Zhang et al. 2018a). The mycelium spreads fast via xylem, producing microconidia that can rapidly invade the plant, generating vascular obstructions caused by hyphae that block the flow of water and nutrients (Ownley and Trigiano, 2016). In addition, the biotic stress caused by the pathogen infection impairs the plant physiology of diseased plants (Villarreal-Navarrete et al., 2017; Chaves-Gómez et al., 2020b). As a result, the visual alterations caused by the disease are chlorosis of the basal leaves, affecting later stages in the entire plant, followed by moderate to severe defoliation, and finally necrosis and death of the plant (Robles Carrión et al., 2014). Moreover, the relationship between inoculum density, early symptom appearance and disease severity has been found in other similar pathosystems (Hao et al., 2009; Caligiore et al., 2014).

Recent research has indicated that the use of optical sensors generates information for disease identification (Zhao et al., 2014; Sterling and Melgarejo, 2020), nutritional status of plants (Martínez and Ramos, 2015; Martínez, 2017) and specific site management of crops (Peng and Gitelson, 2011). Hyperspectral data can be used to identify stress symptoms at an early stage and can be correlated with plant characteristics to support timely decision-making processes in crop management (Lowe et al., 2017). Traditional methods to determine diseases require time to obtain results, which limits adequate decision-making in the field (Brizuela-Amador et al., 2007). On the other hand, spectroradiometric techniques are nondestructive and are based on the measurement of the spectral response of plants, which depends on factors such as phenological status, agronomic management and plant physiological parameters (Martínez, 2017; Thenkabail et al., 2000). A spectroradiometer measures reflectance at different wavelengths and provides information on the nutritional, health and water status of a crop, which can improve decisionmaking and management practices (Zarco-Tejada et al., 2004).

For plant diseases, mainly vascular wilts, the spectral responses of infected plants have been generated for only a low number of pathosystems, such as Capsicum annuum and Verticillium dahliae (Sanogo et al., 2008; Bauriegel and Herppich, 2014), Capsicum annuum - Fusarium spp. (Karadağ et al., 2019) and Solanum lycopersicum and F. oxysporum (Marín-Ortiz et al., 2020). Fusarium-diseased pepper (C. annuum) plants were detected with spectral reflections from leaves before symptoms became visible according to Karadağ et al. (2019). The potential to discriminate healthy from diseased plants before visible symptoms was also demonstrated in tomatoes by Marín-Ortiz et al. (2020), based on their spectral response at several wavelengths. Calderón et al. (2105) outlined an automatic procedure to classify plants infected by Verticillium dahliae in olive crops for large scale early detection. These studies contribute to the early detection of plant diseases caused by vascular pathogens. Nevertheless, crops, including the cape gooseberry, require new methods that adequately establish the presence of the pathogen that causes vascular wilt in the initial stages.

It was hypothesized that hyperspectral responses allow the detection of cape gooseberry plants affected by Fusarium vascular wilt independent of the inoculum density of the pathogen. Therefore, the objective of this study was to determine the hyperspectral responses of cape gooseberry plants inoculated with different $F$. oxysporum f. sp. physali propagule densities as the first step for evaluating the potential of noninvasive methods for the detection of disease under a variable inoculum pressure.

\section{MATERIALS AND METHODS}

\section{Plant material and location}

This experiment was carried out in 2016 with 2-month-old 'Colombia' ecotype cape gooseberry plants, which is the most cultivated plant material in the country (Álvarez-Herrera et al., 2019), acquired from the nursery at the Biosystems Center of the Jorge Tadeo Lozano University in Chia (Cundinamarca, Colombia). These plants were maintained in a nursery with daily drip irrigation and fertilization with a Hoagland solution.

The plants were moved to a plastic greenhouse in Bogota $\left(2,556 \mathrm{~m}\right.$ a.s.1., at $4^{\circ} 35^{\prime} 56^{\prime \prime} \mathrm{N}$ and $\left.74^{\circ} 4^{\prime} 51^{\prime \prime} \mathrm{W}\right)$, with an average temperature of $18 \pm 8^{\circ} \mathrm{C}$, relative humidity of $60-95 \%$ and a natural photoperiod of $12 \mathrm{~h}$ (with a light intensity of 66,694 $\pm 10,981$ Lux at full noon radiation); when the substrate moisture fell below field capacity, irrigation was applied 
approximately every $2 \mathrm{~d}$ for 3 weeks. Twenty-two days later, the plants were transplanted in 2.0-L pots that were previously disinfected with $2 \% \mathrm{NaClO}$, using a mixture of soil and rice husk at a 3:1 ratio (v/v) for the substrate. To ensure that the substrate was free of pathogens, it was autoclaved at a temperature of $121^{\circ} \mathrm{C}$ for $45 \mathrm{~min}$ based on the method proposed by Lagos et al. (2007). The plants were irrigated every $2 \mathrm{~d}$ with a nutrient solution at a concentration of 5 $\mathrm{mL} \mathrm{L}^{-1}$ using the commercial product Nutriponic ${ }^{\circledast}$ (nitrogen $3.75 \%$ (nitric N 3.42\%, ammoniacal N 0.34\%); phosphorus $1.73 \%$; potassium $4.29 \%$; calcium $2.44 \%$; magnesium $0.966 \%$; sulfur $0.085 \%$; iron $0.095 \%$; manganese $0.009 \%$; copper $0.001 \%$; zinc $0.002 \%$; boron $0.009 \%$; molybdenum $0.0001 \%$; cobalt $0.00003 \%$; pH 5.8) (Walco S.A., Bogota, Colombia).

\section{Experiment design and sampling}

A completely randomized design with four replicates was used, where the treatments consisted of three F. oxysporum f. sp. physali inoculum densities (0.0, $1.0 \cdot 10^{3}$ and $1.0 \cdot 10^{6}$ conidia $/ \mathrm{mL}$ ). From each repetition, a plant was sampled by taking two leaves, one from the canopy and another from the lower part of the plant; the reflectance was measured at these two plant levels at 7, 14, 21 and 28 days after inoculation (DAI). On the same dates, samples were collected from four plants per treatment, in which the fresh weight was determined, and the leaf area was measured using a Li 3000A portable leaf area meter (LICOR, Lincoln, NE).

\section{Inoculation}

For the inoculation of the cape gooseberry plants, the pathogenic isolate Map5 of Fusarium oxysporum f. sp. physali, which belongs to the fungal collection of the Molecular Microbiology Laboratory of Agrosavia (Mosquera, Colombia), was used as the source of inoculum. The Map5 isolate was cultured in 250 $\mathrm{mL}$ liquid medium of potato dextrose broth (Oxoid $\left.{ }^{\circledR}\right)$ with constant agitation in an orbital shaker (HeidoIph Instruments, Schwabach, Germany) at $125 \mathrm{rpm}$ for $5 \mathrm{~d}$ at room temperature $\left(25^{\circ} \mathrm{C}\right)$ under dark conditions. The plants were inoculated by root dipping (Gardner, 1989; Haglund, 1989) in $50 \mathrm{~mL}$ of the inoculum suspension for $10 \mathrm{~min}$; the roots of the control plants were immersed in sterile distilled water.

\section{Monitoring vascular wilt in cape gooseberry plants}

To follow up on symptom development in each treatment, visual evaluations of plants were conducted at $0,7,10,12,14,17,19,21,24,26,28,31,33$ and 35 DAI. The disease severity in the plants was assessed using the six-level scale proposed by Enciso-Rodríguez et al. (2013) that includes all possible disease expressions, ranging from level 0 for no symptoms to level 5 indicating plants with total turgor loss and dead plants. In addition, a scale was proposed to assess the disease in leaves (Fig. 1), taking into account the description of symptoms reported by Enciso-Rodríguez et al. (2013).

The intensity of the disease in each treatment was estimated by calculating the area under the disease progress curve (AUDPC) with the trapezoidal integration method (Campbell and Madden, 1990; Alves et al., 2017) using equation 1. In this study, the disease in the plants (AUDPC) and the leaves (AUDPCL) was determined considering the degree of severity

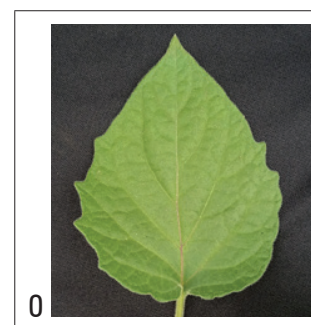

No visible symptoms

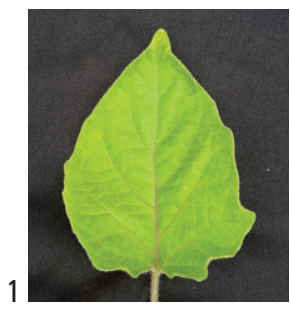

Mild chlorosis, discoloration to pale green and wilting on the edge of the leaf

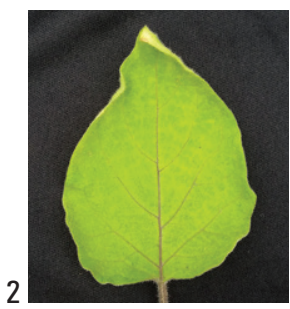

Moderate chlorosis, pale green or slightly yellow and loss of turgor

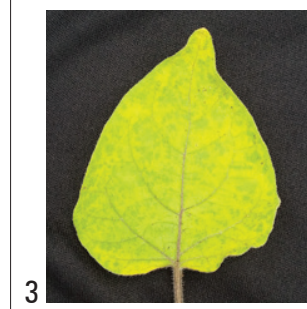

Severe chlorosis, and/or premature defoliation, and loss of turgor

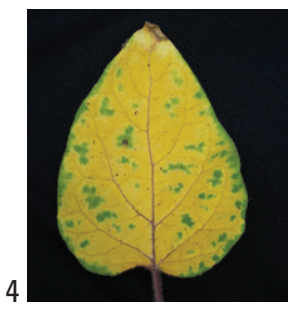

Severe chlorosis, "burned" edges, dead leaves, severe defoliation, and total loss of turgor

Figure 1. Proposed severity scale for the identification of leaf chlorosis caused by the vascular wilt produced by $F$. oxysporum f. sp. physali in cape gooseberry (P. peruviana) plants, adapted from Enciso-Rodríguez et al. (2013). 
that each plant and leaf showed during the evaluation time:

$$
A U D P C=\sum\left[\left(X_{i+1}+X_{i}\right) / 2\right] \times\left[T_{i+1}-T_{i}\right]
$$

where, $i=1, T_{i}=$ number of days between the inoculation and the sampling date, $X_{i}=$ the classification using the symptom scale and $\left[T_{i+1}-T_{i}\right]=$ time in days between two readings.

In addition, cross sections and isolates of the pathogen from the stems and root necks of the inoculated and control plants were performed at 7, 14, 21 and 28 DAI to confirm the presence or absence of the pathogen. Tissue samples were first washed with running water until all visible impurities were removed. Then, they were subjected to a disinfection process in $2 \%$ sodium hypochlorite for $45 \mathrm{~s}$, immersion in $70 \%$ ethanol for $45 \mathrm{~s}$, and finally washed three times in sterile distilled water. Subsequently, the samples were dried with sterile absorbent paper and cultured in potato dextrose agar medium (PDA) $\left(\mathrm{Oxoid}^{\circledR}\right)$ (Inoue et al., 2002; Leslie and Summerell, 2006). After incubation for $7 \mathrm{~d}$ at $25^{\circ} \mathrm{C}$, the presence of mycelial growth and typical colonies of $F$. oxysporum f. sp. physali were evaluated to confirm the pathogen infection in each treatment.

\section{Measurement of the hyperspectral response}

In each replicate, two leaves per plant were sampled, one from the canopy and the other from the lower part of the plant. The reflectance of each leaf was measured with the leaf clip of the FieldSpec $4^{\circledR}$ spectroradiometer (Malvern Panalytical, Malvern, UK), which registers readings between 350 and 2,500 $\mathrm{nm}$ with spectral resolutions of $1.4 \mathrm{~nm}$ from 350 to $1,050 \mathrm{~nm}$ and $2 \mathrm{~nm}$ from 1,050 to $2,500 \mathrm{~nm}$. The leaf clip was used with the plant probe to collect spectra on live vegetation; it has a gentle trigger lock/release gripping system for holding the target sample in position without removing the leaf or inflicting damage. It uses an internal broad-spectrum halogen light source. Before reading the reflectance, the spectroradiometer was standardized to a white reference standard (Spectralon, Labsphere, North Sutton, NH) (ASD, 2012). Four scans were averaged per reflectance spectrum.

Based on the reflectance measurements, the spectral indices shown in table 1 were calculated. These indices were selected because they have performed well in previous studies, showing correlation with plant physiological parameters.

The physiology data and spectral indices were analyzed transversely for each sampled date and tested for normality with the Shapiro-Wilk test; some hyperspectral indices were transformed with Ln to fit a normal distribution. An ANOVA was performed to evaluate the effects of the treatments, and a Tukey test with a significance level of 0.05 was carried out. Pearson's correlation analysis was used to establish the relationships between the physiological variables and spectral indices. Statistical analyses were carried

Table 1. Evaluated spectral indices and red edge positions caused by vascular wilt in the leaves, produced by $F$. oxysporum f. sp. physali, of cape gooseberry (P. peruviana) plants.

\begin{tabular}{|c|c|c|c|c|c|c|}
\hline $\begin{array}{l}\mathscr{d} \\
\text { 응 } \\
\text { 드 }\end{array}$ & $\begin{array}{l}\text { Normalized Differen- } \\
\text { ce Vegetation Index } \\
\text { (NDVI) }\end{array}$ & $\begin{array}{l}\text { Chlorophyll } \\
\text { Red-Edge (ChRE) }\end{array}$ & $\begin{array}{l}\text { Modified Chlorophyll } \\
\text { Absorption Ratio } \\
\text { Index (MCARI) }\end{array}$ & $\begin{array}{l}\text { Blue/Green Index } \\
\text { (BGI) }\end{array}$ & Simple Ratio (SR) & $\begin{array}{l}\text { Zarco and Miller } \\
\text { (ZM) }\end{array}$ \\
\hline 을 & $\begin{array}{l}\text { Good indicator of } \\
\text { nitrogen content, } \\
\text { chlorophyll, biomass, } \\
\text { LAl and yield. Also } \\
\text { provides a medium } \\
\text { estimate of plant } \\
\text { water content }\end{array}$ & $\begin{array}{l}\text { A very sensitive } \\
\text { indicator of the red } \\
\text { edge position and } \\
\text { directly related to } \\
\text { foliar chlorophyll } \\
\text { concentration. The } \\
\text { established index } \\
\text { for non-invasive } \\
\text { in-vivo chlorophyll } \\
\text { determination }\end{array}$ & $\begin{array}{l}\text { Generally, reflectan- } \\
\text { ce of } 705 \text { and } 750 \\
\text { nm is more suitable } \\
\text { for a chlorophyll } \\
\text { content estimation; } \\
\text { developed for } \\
\text { chlorophyll content } \\
\text { variations. A better } \\
\text { indicator of LAl, } \\
\text { when LAl < } 6\end{array}$ & $\begin{array}{l}\text { This index has very } \\
\text { good relationships } \\
\text { with the chlorophyll } \\
\text { a and b contents } \\
\text { (Cab), which are an } \\
\text { indicator of plant } \\
\text { stress and growth }\end{array}$ & $\begin{array}{l}\text { This index was } \\
\text { developed for } \\
\text { chlorophyll content } \\
\text { (Ch/) assessments } \\
\text { because (R550) }{ }^{-1} \text { is } \\
\text { directly proportional } \\
\text { to Ch/ and enable } \\
\text { Ch/ estimations in } \\
\text { dark-green to yellow } \\
\text { leaves }\end{array}$ & $\begin{array}{l}\text { Has linear relations- } \\
\text { hips with chlorophyll } \\
\text { a (Ca), chlorophyll b } \\
\text { (Cb), and Cab (indi- } \\
\text { cator of plant stress } \\
\text { and growth) }\end{array}$ \\
\hline 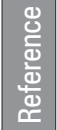 & $\begin{array}{l}\text { Katsoulas et al. } \\
\text { (2016) }\end{array}$ & $\begin{array}{l}\text { Gitelson et al. } \\
\text { (1996) }\end{array}$ & Wu et al. (2008) & $\begin{array}{l}\text { Zarco-Tejada et al. } \\
\text { (2005) }\end{array}$ & $\begin{array}{l}\text { Gitelson and } \\
\text { Merzlyak (1997) }\end{array}$ & $\begin{array}{l}\text { Zarco-Tejada et al. } \\
\text { (2005) }\end{array}$ \\
\hline
\end{tabular}


out with IBM SPSS STATISTICS 23 (International Business Machines Corporation, Armonk, NY).

\section{RESULTS AND DISCUSSION}

The results of this experiment were analyzed but only the data obtained in the evaluations done at 7 , 14 and 21 DAI are shown because, after 18 DAI, the cape gooseberry plants had already expressed severe visual symptoms of the disease.

\section{Monitoring vascular wilt in cape gooseberry plants inoculated with Fusarium oxysporum}

At 7 DAI, there were no symptoms of the disease in any of the treatments (Fig. 2). The evaluation of the disease indicated that, with the high inoculum density $\left(1.0 \cdot 10^{6}\right.$ conidia/mL), wilt symptoms appeared faster than in the other treatments; at 14 DAI, the plants of this treatment had a higher degree of disease severity, grade 1 , characterized by mild chlorosis, dark green to light green leaves, interveinal chlorosis of leaves, slight turgor loss and more than 10\% damage in the plant.

The assessment of the pathogen colonization in stems and root necks of inoculated and control plants in PDA culture medium confirmed the presence of the pathogen in the sampled tissue of the inoculated plants. In this case, typical F. oxysporum colonies were obtained from the inoculated plants. No F. oxysporum colonies were isolated from the control plants at any of the conducted evaluations.

At $21 \mathrm{DAI}$, the treatment with $1 \cdot 10^{6}$ conidia $/ \mathrm{mL}$ reached disease severity grade 4 , and, at 26 DAI, mortality for most of the plants was observed. The inoculum density of $1.0 \cdot 10^{3}$ conidia/mL showed severity grade 1 starting at $17 \mathrm{DAI}$, and, at $21 \mathrm{DAI}$, the AUDPC value was 7.83 for the treatment under $1.0 \cdot 10^{3}$ conidia $/ \mathrm{mL}$. In contrast, the treatment with $1.0 \cdot 10^{6}$ conidia/mL had values of 29.16 , which were significantly higher than the other treatments (Fig. 3a). Similar results were found by Villarreal-Navarrete et al. (2017) who reported that symptomatology was visually evident at 18 DAI in plants inoculated with F. oxysporum and subjected to a flood period.

When evaluating the severity of each of the leaves, the degree of the disease was verified with the severity scale established for the experiment (Fig. 1). The
$1.0 \cdot 10^{6}$ conidia $/ \mathrm{mL}$ treatment showed significant differences from the other treatments starting at 7 DAI (Fig. 3B), with values of 26.06 for the AUDPCL at 21 DAI. Symptoms of the disease indicated a higher degree of the disease in the treatments with a high inoculum density, showing a severity grade of 2 at 17 DAI, which corresponded to mild chlorosis and loss of turgor. The treatments with a low conidial density had a AUDPCL value of 6.76 at 31 DAI. Although low chlorosis values were registered in the control plants $(0.0$ and 0.15$)$ with the scale, this symptom was related to a greenery loss in lower leaves, due to the fact that no presence of $F$. oxysporum $f$. sp. physalis was confirmed in control plants in the laboratory test as mentioned before.

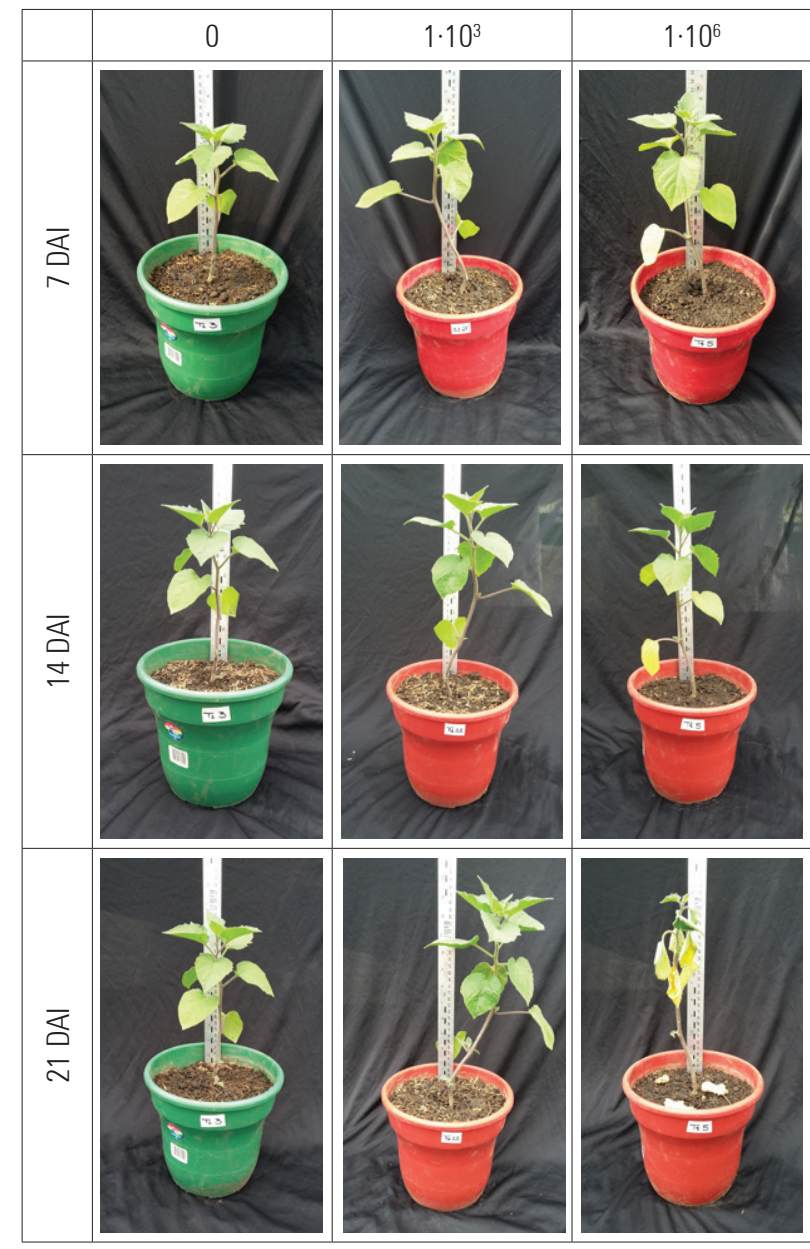

Figure 2. Development of vascular wilt severity in cape gooseberry (Physalis peruviana) 'Colombia' ecotype plants inoculated with three Fusarium oxysporum f. sp. physali densities: $0,1 \cdot 10^{3}, 1 \cdot 10^{6}$ conidia/mL and kept under greenhouse conditions. DAl: days after inoculation. 


\section{Spectral response in cape gooseberry plants inoculated with Fusarium oxysporum}

The reflectance of the leaves at 14 and 21 DAI showed differences over a large part of the spectrum (Fig. 4A). At $14 \mathrm{DAI}$, in the visible spectrum $(400-700 \mathrm{~nm}$ ) (Fig. $4 \mathrm{~B})$, the reflectance had values between 0.1 for the treatments with a low pathogen density and without the pathogen and 0.32 for the treatment with $1.0 \cdot 10^{6}$ conidia/mL. This indicated that the energy that reaches the surface of leaves in this range of the spectrum is reflected in a higher proportion in plants inoculated with a high-density of inoculum. This effect is caused by physiological parameters that alter the absorption of light in cells (Taiz et al., 2015) as a result of pathogen infection in plants, which reduces the uptake of nutrients and water. Pathogens can induce physiological stresses and physical changes in plants, such as chlorosis, necrosis, abnormal growth, and dwarfism, among other alterations (Nutter and Gaunt, 1996; Ghaemi et al., 2011; Chávez-Arias et al., 2019; Cháves-Gómez et al., 2020a). These changes can alter the reflectance properties of plants (Oin et al., 2009; Mahlein et al., 2010; Karadağ et al., 2019; Marín-Ortiz et al., 2020). Naidu et al. (2009) found that grapevine cultivars affected by a leafroll-associated virus showed maximum difference in reflectance between healthy and diseased plants at 550 and $680 \mathrm{~nm}$, and MacDonald et al. (2016) that the use of hyperspectral imaging is useful for mapping diseased vines. Prabhakar et al. (2013) indicated that an increase in mosaic disease severity in black beans (Vigna mungo) caused a decrease in the relative chlorophyll content and the percentage of foliar nitrogen.

At 14 DAI, the plants inoculated with $1.0 \cdot 10^{6}$ conidia/ $\mathrm{mL}$ had higher reflectance between 500 and $733 \mathrm{~nm}$, with a peak at $551 \mathrm{~nm}$, and a value of 0.31 , while the other treatments had an average reflectance value of 0.14 (Fig. 4B). Bauriegel and Herppich (2014) found that, for a different disease, 550 to $560 \mathrm{~nm}$ is the optimal range for detecting fusariosis in spikes of Triticum sativum, while Bauriegel et al. (2011) indicated that this range lies between 665 and $675 \mathrm{~nm}$. The reduction of the chlorophyll content in cells reduces the potential of the processes of remission and reabsorption of internal photons in the relevant wavelength range, causing photosynthetic processes that lead to a change in the red edge position (Zhang et al., 2018b).

The differences in the reflectance values, the near infrared (NIR), the visible range and the red edge at 14 DAI can be associated with stress caused by diseases in the plants between the control and the treatments that were inoculated with $F$. oxysporum $\mathrm{f}$. sp. physali (Fig. 4A). Similar results have been reported in other soil plant pathogens, such as basal stipe rot, caused by the basidiomycete fungus Ganoderma boninense Pat in oil palm (Shafri et al., 2011; Ahmadi et al., 2017). Additionally, in a contrasting pathosystem, such as

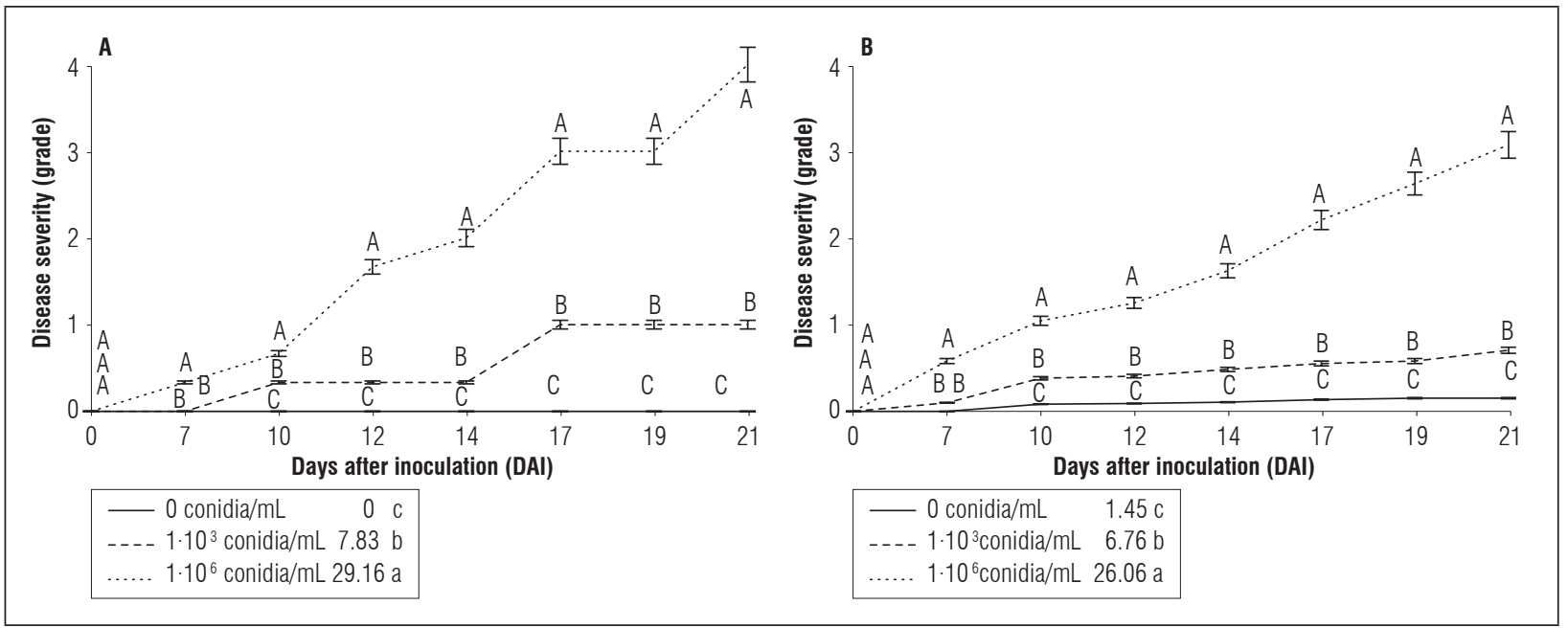

Figure 3. Disease severity of cape gooseberry (P. peruviana) plants inoculated with $F$. oxysporum f. sp. physali for a period of 21 DAl according to an adapted Enciso-Rodríguez et al. (2013) severity scale. A, plants and B, leaves. The values next to the figure legend represent the area under the disease curve (A. AUDPC and B. AUDPCL) until 21 DAI for each treatment. Bars indicate the standard error. Means with different letters indicate significant differences according to the Tukey test $(P \leq 0.05)$. 

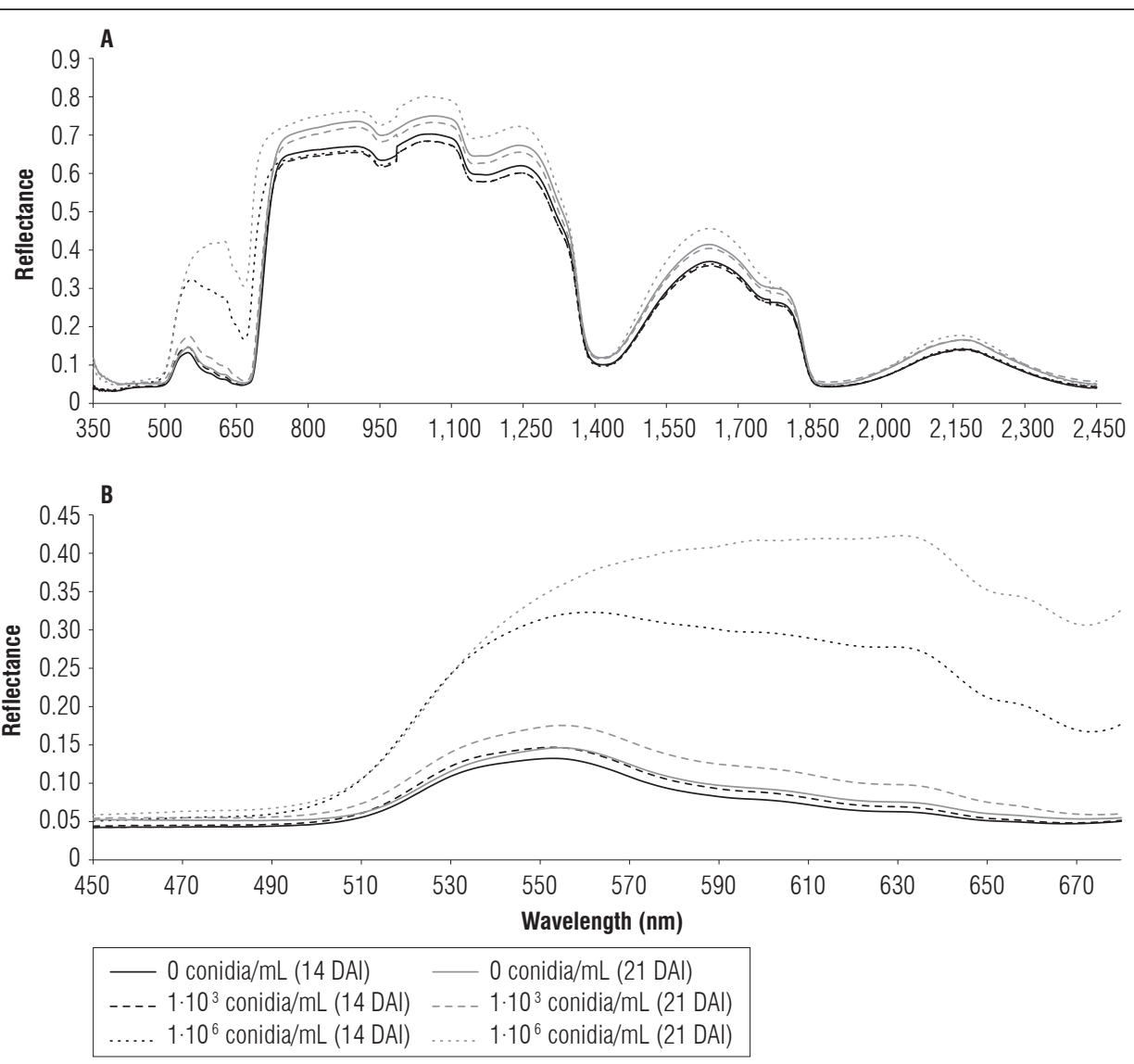

Figure 4. Average spectral response of cape gooseberry 'Colombia' ecotype plants inoculated with $F$. oxysporum $\mathrm{f}$. sp. physali. A, range from 350 to $2,500 \mathrm{~nm}$ and $B$, range from 350 to $2,500 \mathrm{~nm} 14$ and 21 DAl. $n=8$ samples per treatment.

Table 2. Correlation coefficients established for spectral indices in cape gooseberry plants inoculated with $F$. oxysporum f. sp. physali 14 days after inoculation. ${ }^{*} P \leq 0.05,{ }^{*} P \leq 0.01$.

\begin{tabular}{|l|c|c|c|c|}
\hline Variables & Leaf area & Fresh weight aerial part & AUDPC $^{1}$ & AUDPCL $^{2}$ \\
\hline Leaf area & 1 & & & \\
\hline Fresh weight aerial part & 0.756 & 1 & 1 & 1 \\
\hline AUDPC & $-0.910^{*}$ & -0.505 & $-0.946^{* *}$ & -0.798 \\
\hline AUDPCL & $-0.950^{* *}$ & -0.714 & -0.624 & $-0.883^{*}$ \\
\hline NDVI & $0.860^{*}$ & $0.982^{* *}$ & -0.742 & $-0.882^{*}$ \\
\hline ChRE & $0.906^{*}$ & $0.945^{* *}$ & -0.737 & $-0.886^{*}$ \\
\hline MCARI & $0.900^{*}$ & $0.942^{* *}$ & -0.734 & $-0.880^{*}$ \\
\hline SR & $0.895^{*}$ & $0.951^{* *}$ & -0.728 & \\
\hline ZM & $0.897^{*}$ & $0.949^{* *}$ & & \\
\hline
\end{tabular}

AUDPC, Area Under the Disease Progress Curve; AUDPCL, Area Under the Disease Progress Curve on Leaves; NDVI, Normalized Difference Vegetation Index; ChRE, Chlorophyll Index at the Edge of Red; MCARI, Modified Chlorophyll Absorption Index; SR, Simple ratio; ZM, Index of Zarco and Miller. 
Fusarium culmorum infecting wheat spikes, Kang and Buchenauer (2000) stated that stress associated with the disease generates a rapid and irreversible degradation of chlorophyll as a result of the destruction of chloroplasts and gradual decomposition of organelles in plant cells.

At 21 DAI, the plants inoculated with $1.0 \cdot 10^{6}$ conidia/ $\mathrm{mL}$ had higher reflectance than the other treatments between 500 and $1300 \mathrm{~nm}$, and the effect of the $1.0 \cdot 10^{3}$ conidia $/ \mathrm{mL}$ on reflectance was less intense
(Fig. 4). The spectral indices were calculated with the reflectance data (Tab. 1). The indices that had a greater relationship with the AUDPC, for the follow-up of the vascular wilting and the growth of the plants, included SR, ZM, ChRE, NDVI and MCARI.

Although the SR and ZM indices showed a similar trend over time for all treatments (Fig. 5), significant differences were observed at 21 DAI, with values of 2.12 for SR and 1.09 for ZM in the high-density $F$. oxysporum f. sp. physali inoculum treatment $\left(1 \cdot 10^{6}\right.$
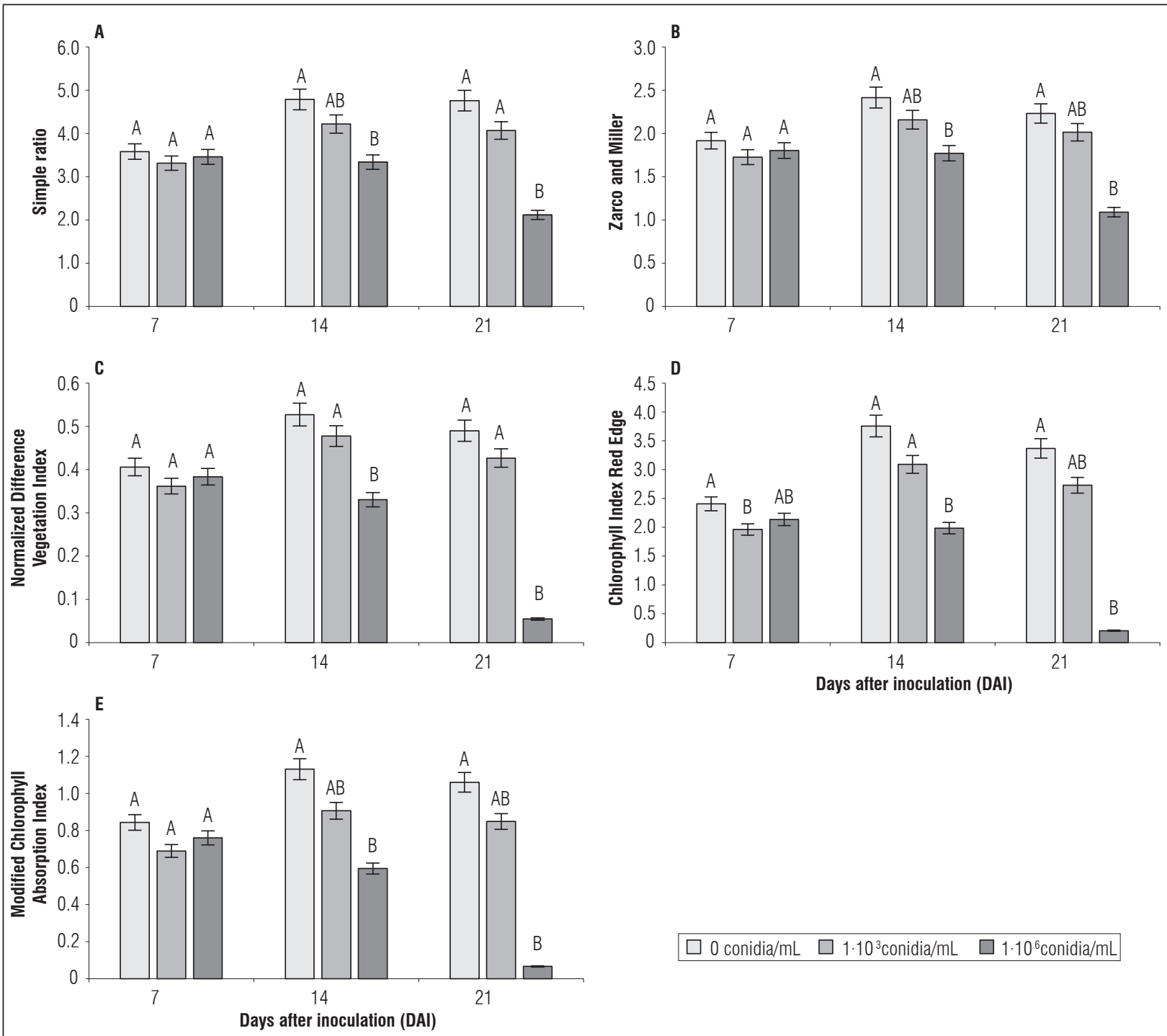

0 conidia/mL $\square 1 \cdot 10^{3}$ conidia/mL $\square 1 \cdot 10^{6}$ conidia/mL

Figure 5. Spectral indices in cape gooseberry (P. peruviana) plants inoculated with different inoculum densities of $F$. oxysporum f. sp. physali 14 days after inoculation (DAI). A, simple ratio; B, Zarco and Miller; C, Normalized Difference Vegetation Index; D, Chlorophyll Index Red Edge and E, Modified Chlorophyll Absorption Index. Bars indicate the standard error. Means with different letters at each sampling point indicate significant differences according to the Tukey test $(P \leq 0.05)$. 
conidia $/ \mathrm{mL}$ ). These values were the lowest, followed by the low-density treatment of $F$. oxysporum $\mathrm{f}$. sp. physali $\left(1 \cdot 10^{3}\right.$ conidia/mL), whose values were 4.07 and 2.01 for SR and ZM, respectively. On the other hand, the results of NDVI, ChRE and MCARI showed significant differences between the treatments, with values of $0.33,1.99,0.59$, respectively, at 14 DAI (Fig. $5)$. These results confirmed that spectral vegetation indices are useful for the indirect detection of plant diseases, as reported by Mahlein et al. (2013) and Lu et al. (2017).

The indices described above were proposed to estimate the absorption of light by chlorophyll, which is most noticeable in the red spectrum $(670 \mathrm{~nm})$ (Lichtenthaler et al., 1996); in turn, Zhao et al. (2005) indicated that the nitrogen content in tissues is proportional to the reflectance in the near infrared region (NIR). Therefore, crops that are in better nutritional conditions, particularly nitrogen, will exhibit a higher content of this element in their leaves and will reflect higher values of the spectrum in this region.

Gitelson et al. (1996) found a strong relationship between the chlorophyll concentration of leaves and the reflectance coefficients (R750/R695 and R750/ R700), which belong to the near infrared; this explains the behavior of this region of the spectrum during the development of the experiment because, the higher the radiation reflected in the NIR region, the higher the nitrogen contents in the plant are and the higher the index values are (Mistele and Schmidhalter, 2007). On the other hand, Sanogo et al. (2008) indicated that, in C. annuum plants affected by $V$. dahliae and subjected to flooding, an analysis of variance revealed significant main and interactive effects for the photochemical reactive index (PRI) and the AUDPC for plants under the two stresses. In this study, the spectral response of cape gooseberry plants 'Colombia' ecotype to vascular wilt caused by F. oxysporum f. sp. physali was obtained but additional studies are needed to characterize spectral responses to factors involved in water stress in order to differentiate pathogen-induced wilt from drought-induced wilt. Nevertheless, the indices calculated in the current study had a correlation $>0.7$ with the AUDPC and $>0.8$ with the AUDPCL, caused by F. oxysporum $\mathrm{f}$. sp. physali (Tab. 2), indicating that indices evaluated from spectral responses can be used for the detection of this disease.

\section{CONCLUSIONS}

This research showed the potential of spectral responses in the study of the P. peruviana - F. oxysporum pathosystem and vascular wilt detection in cape gooseberry plants. The factor pathogen inoculum density showed significant differences between the treatments in the severity of the disease and the physiological and spectral response of the plants from the second sampling (14 DAI) as a result of the aggressiveness of the pathogen and susceptibility of the evaluated cape gooseberry ecotype. The spectral responses of the plants inoculated with $F$. oxysporum f. sp. physali registered significant differences from those in the control plants. These differences were mainly detected in the visible region of the spectrum, becoming more evident with time and according to the high inoculum densities to which the plants were exposed. The NDVI, ChRE, MCARI, SR and ZM spectral indices differentiated healthy plants from plants inoculated with the pathogen; in addition, they showed the highest correlation coefficients for the disease severity in the leaves and the physiological variables 14 days after inoculation.

Conflict of interests: The manuscript was prepared and reviewed with the participation of the authors, who declare that there exists no conflict of interest that puts at risk the validity of the presented results.

\section{BIBLIOGRAPHIC REFERENCES}

Agronet. 2020. Estadísticas - uchuva. In: http://www.agronet.gov.co; consulted: January, 2020.

Ahmadi, P., F.M. Muharam, K. Ahmad, S. Mansor, and I.A. Seman. 2017. Early detection of ganoderma basal stem rot of oil palms using artificial neural network spectral analysis. Plant Dis. 101(6), 1009-1016. Doi: 10.1094/ PDIS-12-16-1699-RE

Álvarez-Herrera, J., H. González, and G. Fischer. 2019. Water potential in cape gooseberry (Physalis peruviana L.) plants subjected to different irrigation treatments and doses of calcium. Agron. Colomb. 37(3), 274-282. Doi: 10.15446/agron.colomb.v37n3.79935

Alves, D.P., R.S. Tomaz, B.S. Laurindo, R.D.F. Laurindo, C.D. Cruz, C. Nick, and D.J.H.D. Silva. 2017. Artificial neural network for prediction of the area under the disease progress curve of tomato late blight. Sci. Agric. 74(1), 51-59. Doi: 10.1590/1678-992x-2015-0309 
ASD Inc. 2012. FieldSpec 4 user guide. ASD document 6000979. Malvern Panalytical, Malvern, UK.

Bauriegel, E., A. Giebel, and W. Herppich. 2011. Hyperspectral and chlorophyll fluorescence imaging to analyse the impact of Fusarium culmorum on the photosynthetic integrity of infected wheat ears. Sensors 11, 37653779. Doi: 10.3390/s110403765

Bauriegel, E. and W. Herppich. 2014. Hyperspectral and chlorophyll fluorescence imaging for early detection of plant diseases, with special reference to Fusarium spec. infections on wheat. Agriculture 4, 32-57. Doi: 10.3390/agriculture4010032

Brizuela-Amador, B., G. Alcántar-González, P. Sánchez-García, Y. Pea-Kalra, J. Crumbaugh, C. Olive, and R. Maldonado-Torres. 2007. Establecimiento de índices espectrales en el diagnóstico nutrimental de nitrógeno en maíz. Agrociencia 41, 827-835.

Calderón, R., J.A. Navas-Cortés, and P.J Zarco-Tejada. 2015. Early detection and quantification of Verticillium wilt in olive using hyperspectral and thermal imagery over large areas. Remote Sens. 7(5), 5584-5610. Doi: $10.3390 /$ rs 70505584

Caligiore, P.F., J.G. Valdez, R.J. Piccolo, and C.R. Galmarini. 2014. Influence of Fusarium spp. isolate and inoculum density on resistance screening tests in onion. Trop. Plant Pathol. 39(1), 019-027. Doi: 10.1590/ S1982-56762014005000005

Campbell, C.L. and L.V. Madden. 1990. Introduction to plant disease epidemiology. Wiley-Interscience, New York, NY.

Cháves-Gómez J.L., L.M. Becerra-Mutis, C.C. Chávez-Arias, H. Restrepo-Díaz, and S. Gómez-Caro. 2020a. Screening of different Physalis genotypes as potential rootstocks or parents against vascular wilt using physiological markers. Front. Plant Sci. 11, 806. Doi: $10.3389 /$ fpls.2020.00806

Chaves-Gómez, J.L., A.M. Cotes-Prado, S. Gómez-Caro, and H. Restrepo-Díaz. 2020b. Physiological response of cape gooseberry seedlings to two organic additives and their mixture under inoculation with Fusarium oxysporum f. sp. physali. HortScience 55(1), 121-132. Doi: 10.21273/HORTSCI14550-19

Chávez-Arias, C.C., S. Gómez-Caro, and H. Restrepo-Díaz. 2019. Physiological, biochemical and chlorophyll fluorescence parameters of Physalis peruviana L. seedlings exposed to different short-term waterlogging periods and Fusarium wilt infection. Agron. 9, 213. Doi: 10.3390/agronomy 9050213

Cruz, M., L. Hoyos-Carvajal, and L.M. Melgarejo. 2012. Respuesta fisiológica de la Gulupa (Passiflora edulis Sims) frente al ataque por Fusarium spp. pp. 91-113. In: Melgarejo, L.M. (ed.). Ecofisiologia del cultivo de la Gulupa (Passiflora edulis Sims). Universidad Nacional de Colombia, Bogota.
Enciso-Rodríguez, F.E., C. González, E.A. Rodríguez, C.E. López, D. Landsman, L.S. Barrero, and L. Mariño-Ramírez. 2013. Identification of immunity related genes to study the Physalis peruviana - Fusarium oxysporum pathosystem. PLoS ONE 8(7), e68500. Doi: 10.1371/ journal.pone.0068500

Fischer, G., P.J. Almanza-Merchán, and D. Miranda. 2014. Importancia y cultivo de la uchuva (Physalis peruviana L .). Rev. Bras. Frutic. 36(1), 1-15. Doi: 10.1590/0100-2945-441/13

Fischer, G. and L.M. Melgarejo. 2020. The ecophysiology of cape gooseberry (Physalis peruviana L.) - an Andean fruit crop. A review. Rev. Colomb. Cienc. Hortic. 14(1). Doi: 10.17584/rcch.2020v14i1.10893

Gardner, D.E. 1989. Pathogenicity of Fusarium oxysporum f. sp. passiflorae to banana poka and other Passiflora spp. in Hawaii. Plant Dis. 73(6), 476-478. Doi: 10.1094/ PD-73-0476

Ghaemi, A., A. Rahimi, and Z. Banihashemi. 2011. Effects of water stress and Fusarium oxysporum f. sp. lycoperseci on growth (leaf area, plant height, shoot dry matter) and shoot nitrogen content of tomatoes under greenhouse conditions. Iran. Agric. Res. 29, 51-62.

Gitelson, A. and M.N. Merzlyak. 1997. Remote estimation of chlorophyll content in higher plant leaves. Int. J. Remote Sens. 18(12), 2691-2697. Doi: 10.1080/014311697217558

Gitelson, A.A., M.N. Merzlyak, and H.K. Lichtenthaler. 1996. Detection of red edge position and chlorophyll content by reflectance measurements near $700 \mathrm{~nm}$. J. Plant Physiol. 148(3-4), 501-508. Doi: 10.1016/ S0176-1617(96)80285-9

Gullino, M.L., M.L. Daughtrey, A. Garibaldi, and W.H. Elmer. 2015. Fusarium wilts of ornamental crops and their management. Crop Prot. 73, 50-59. Doi: 10.1016/j.cropro.2015.01.003

Haglund, W.A. 1989. A rapid method for inoculating pea seedlings with Fusarium oxysporum $f$. sp. pisi. Plant Dis. 73(6), 457-458. Doi: 10.1094/PD-73-0457

Hao, J.J., M.E. Yang, and R.M. Davis. 2009. Effect of soil inoculum density of Fusarium oxysporum f. sp. vasinfectum race 4 on disease development in cotton. Plant Dis. 93, 1324-1328. Doi: 10.1094/PDIS-93-12-1324

Inoue, I., F. Namiki, and T. Tsuge. 2002. Plant colonization by the vascular wilt fungus Fusarium oxysporum Requires FOW1, a gene encoding a mitochondrial protein. Plant Cell 14, 1869-1883. Doi: 10.1105/tpc.002576

Kang, Z. and H. Buchenauer. 2000. Cytology and ultrastructure of the infection of wheat spikes by Fusarium culmorum. Mycol. Res. 104(9), 1083-1093. Doi: 10.1017/S0953756200002495

Karadağ, K., M.E. Tenekeci., R. Taşaltın, and A. Bilgili. 2019. Detection of pepper fusarium disease using machine learning algorithms based on spectral reflectance. 
Sustain. Comput. Infor. Syst. 100299. Doi: 10.1016/j. suscom.2019.01.001

Katsoulas, N., A. Elvanidi, K.P. Ferentinos, M. Kacira, T. Bartzanas, and C. Kittas. 2016. Crop reflectance monitoring as a tool for water stress detection in greenhouses: A review. Biosyst. Eng. 151, 374-398. Doi: 10.1016/j.biosystemseng.2016.10.003

Lagos, J.A., R. Campos, and C. Fuentes. 2007. Efecto del herbicida Atrazina sobre la población de bacterias en un suelo del municipio de Saldaña, Tolima. Colomb. For. 10(20), 161-179. Doi: 10.14483/udistrital.jour.colomb.for.2007.1.a09

Lecomte, C., C. Alabouvette, V.E. del-Hermann, F. Robert, and C. Steinberg. 2016. Biological control of ornamental plant diseases caused by Fusarium oxysporum: A review. Biol. Contr. 101, 17-30. Doi: 10.1016/j. biocontrol.2016.06.004

Leslie, J.F. and B.A. Summerell. 2006. The fusarium laboratory manual. Wiley-Blackwell, Hoboken, NJ. Doi: 10.1002/9780470278376

Lichtenthaler, H.K., A. Gitelson, and M. Lang. 1996. Non-destructive determination of chlorophyll content of leaves of a green and an aurea mutant of tobacco by reflectance measurements. J. Plant Physiol. 148, 483-493. Doi: 10.1016/S0176-1617(96)80283-5

Lowe, A., N. Harrison, and A.P. French. 2017. Hyperspectral image analysis techniques for the detection and classification of the early onset of plant disease and stress. Plant Meth. 13(1), 1-12. Doi: 10.1186/ s13007-017-0233-z

Lu, J., R. Ehsani, Y. Shi, J. Abdulridha, A.I. de Castro, and Y. Xu. 2017. Field detection of anthracnose crown rot in strawberry using spectroscopy technology. Comp. Electron. Agric. 135, 289-299. Doi: 10.1016/j. compag.2017.01.017

MacDonald, S.L., M. Staid, M. Staid, and M.L. Cooper. 2016. Remote hyperspectral imaging of grapevine leafroll-associated virus 3 in cabernet sauvignon vineyards. Comp. Electron. Agric. 130, 109-117. Doi: 10.1016/j.compag.2016.10.003

Mahlein, A.K., T. Rumpf, P. Welke, H.W. Dehne, L. Plümer, U. Steiner, and E.C. Oerke. 2013. Development of spectral indices for detecting and identifying plant diseases. Remote Sens. Environ. 128, 21-30. Doi: 10.1016/j.rse.2012.09.019

Mahlein, A.K., U. Steiner, H.-W. Dehne, and E.-C. Oerke. 2010. Spectral signatures of sugar beet leaves for the detection and differentiation of diseases. Precision Agric. 11, 413-431. Doi: 10.1007/s11119-010-9180-7

Marín-Ortiz, J.C., N. Gutierrez-Toro, V. Botero-Fernández, and L.M. Hoyos-Carvajal. 2020. Linking physiological parameters with visible/near-infrared leaf reflectance in the incubation period of vascular wilt disease. Saudi J. Biol. Sci. 27(1), 88-99. Doi: 10.1016/j. sjbs.2019.05.007
Martínez, L.J. 2017. Relationship between crop nutritional status, spectral measurements and Sentinel 2 images. Agron. Colomb. 35(2), 205-215. Doi: 10.15446/agron. colomb.v35n2.62875

Martínez, L.J. and A. Ramos. 2015. Estimation of chlorophyll concentration in maize using spectral reflectance. pp. 65-71. In: Proc. 36 $6^{\text {th }}$, International Archives of the Photogrammetry, Remote Sensing and Spatial Information Sciences. XL-7/W3. ISPRS, Berlin. Doi: 10.5194/isprsarchives-XL-7-W3-65-2015

McGovern, R.J. 2015. Management of tomato diseases caused by Fusarium oxysporum. Crop Prot. 73, 78-92. Doi: 10.1016/j.cropro.2015.02.021

Mistele, B. and U. Schmidhalter. 2007. Spectral measurements of the total aerial $\mathrm{N}$ and biomass dry weight in maize using a quadrilateral-view optic. Field Crops Res. 106(1), 94-103. Doi: 10.1016/j.fcr.2007.11.002

Naidu, R.A., E.M. Perry, F.J. Pierce, and T. Mekuria. 2009. The potential of spectral reflectance technique for the detection of grapevine leafroll-associated virus-3 in two red-berried wine grape cultivars. Comp. Electron. Agric. 66(1), 38-45. Doi: 10.1016/j. compag.2008.11.007

Nutter, F.W. and R.E. Gaunt. 1996. Recent developments in methods for assessing disease losses in forage/pasture crops. Pasture Forage Crop Pathol. Jan. 1996, 93-118. Doi: 10.2134/1996.pastureforagecroppathol.c6

Ownley, B.H. and R.N. Trigiano (eds.). 2016. Plant pathology: Concepts and laboratory exercises. CRC Press, Boca Raton, FL.

Peng, Y. and A.A. Gitelson. 2011. Application of chlorophy11-related vegetation indices for remote estimation of maize productivity. Agric. For. Meteor. 151(9), 12671276. Doi: 10.1016/j.agrformet.2011.05.005

Prabhakar, M., Y.G. Prasad, S. Desai, M. Thirupathi, K. Gopika, G.R. Rao, and B. Venkateswarlu. 2013. Hyperspectral remote sensing of yellow mosaic severity and associated pigment losses in Vigna mungo using multinomial logistic regression models. Crop Prot. 45, 132140. Doi: 10.1016/j.cropro.2012.12.003

Qin, J., T.F. Burks, M.A. Ritenour, and W.G. Bonn. 2009. Detection of citrus canker using hyperspectral reflectance imaging with spectral information divergence. J. Food Eng. 93(2), 183-191. Doi: 10.1016/j. jfoodeng.2009.01.014

Robles Carrión, A., R. Gómez Criollo, F. Marcas Rojas, A. Sánchez Rodríguez, and R. Torres-Gutiérrez. 2014. Study of pathogenicity of Fusarium spp. isolates, associated with vascular wilt Babaco in Loja - Ecuador. Centro Biotecnol. 3(1), 61-72.

Sanogo, S., O.I. El-Sebai, and R. Sanderson. 2008. Severity of verticillium wilt, plant growth, and spectral reflectance indices of chile pepper under periodic flooding and no-flooding conditions. HortScience 43(2), 414419. Doi: 10.21273/HORTSCI.43.2.414 
Shabani, F., L. Kumar, and A. Esmaeili. 2014. Future distributions of Fusarium oxysporum f. spp. in European, Middle Eastern and North African agricultural regions under climate change. Agric. Ecosyst. Environ. 197, 96-105. Doi: 10.1016/j.agee.2014.08.005

Shafri, H.Z.M., M.I. Anuar, I.A. Seman, and N.M. Noor. 2011. Spectral discrimination of healthy and ganoderma-infected oil palms from hyperspectral data. Int. J. Remote Sensing 32(22), 7111-7129. Doi: 10.1080/01431161.2010.519003

Sharma, A., N.K. Sharma, A. Srivastava, A. Kataria, S. Dubey, S. Sharma, and B. Kundu. 2018. Clove and lemongrass oil based non-ionic nanoemulsion for suppressing the growth of plant pathogenic Fusarium oxysporum f.sp. lycopersici. Ind. Crops Prod. 123, 353362. Doi: 10.1016/j.indcrop.2018.06.077

Simbaqueba, J., A.M. Catanzariti, C. González, and D.A. Jones. 2018. Evidence for horizontal gene transfer and separation of effector recognition from effector function revealed by analysis of effector genes shared between cape-gooseberry- and tomato-infecting formae speciales of Fusarium oxysporum. Mol. Plant Pathol. 19, 2302-2318. Doi: 10.1111/mpp.12700

Southwood, M.J., A. Viljoen, and A. McLeod. 2015. Inoculum sources of Fusarium oxysporum f.sp. cepae on onion in the Western Cape Province of South Africa. Crop Prot. 75, 88-95. Doi: 10.1016/j.cropro.2015.05.014

Sterling, A. and L.M. Melgarejo. 2020. Leaf spectral reflectance of Hevea brasiliensis in response to Pseudocercospora ulei. Eur. J. Plant Pathol. 156(4), 1063-1076. Doi: 10.1007/s10658-020-01961-7

Taiz, L., E. Zeiger, I.M. Møller, and A. Murphy. 2015. Plant physiology and development. $6^{\text {th }}$ ed. Sinauer Associates, Sunderland, MA.

Thenkabail, P.S., R.B. Smith, and E. De Pauw. 2000. Hyperspectral vegetation indices and their relationships with agricultural crop characteristics. Remote Sens. Environ. 71(2), 158-182. Doi: 10.1016/ S0034-4257(99)00067-X

Villarreal-Navarrete, A., G. Fischer, L.M. Melgarejo, G. Correa, and L. Hoyos-Carvajal. 2017. Growth response of the cape gooseberry (Physalis peruviana L) to waterlogging stress and Fusarium oxysporum infection. Acta Hortic. 1178, 161-168. Doi: 10.17660/ ActaHortic.2017.1178.28

Wu, C., Z. Niu, O. Tang, and W. Huang. 2008. Estimating chlorophyll content from hyperspectral vegetation indices: Modeling and validation. Agric. For. Meteor. 148(8-9), 1230-1241. Doi: 10.1016/j. agrformet.2008.03.005

Zarco-Tejada, P.J., A. Berjón, R. López-Lozano, J.R. Miller, P. Martín, V. Cachorro, M.R. González, and A. De Frutos. 2005. Assessing vineyard condition with hyperspectral indices: Leaf and canopy reflectance simulation in a row-structured discontinuous canopy. Remote Sens. Environ. 99(3), 271-287. Doi: 10.1016/j. rse.2005.09.002

Zarco-Tejada, P.J., J.R. Miller, A. Morales, A. Berjón, and J. Agüera. 2004. Hyperspectral indices and model simulation for chlorophyll estimation in open-canopy tree crops. Remote Sens. Environ. 90(4), 463-476. Doi: 10.1016/j.rse.2004.01.017

Zhang, Y., L. Guanter, J. Joiner, L. Song, and K. Guan. 2018 b. Spatially-explicit monitoring of crop photosynthetic capacity through the use of space-based chlorophyll fluorescence data. Remote Sens. Environ. 210, 362374. Doi: 10.1016/j.rse.2018.03.031

Zhang, Z., W. Ren, J. Wang, W. Chen, C. Sang, and C. Chen. 2018a. Resistance risk assessment of Fusarium oxysporum $\mathrm{f}$. sp. melonis against phenamacril, a myosin inhibitor. Pesticide Biochem. Physiol. 147(Sept. 2017), 127-132. Doi: 10.1016/j.pestbp.2017.09.014

Zhao, J., L. Huang, W. Huang, D. Zhang, L. Yuan, J. Zhang, and D. Liang. 2014. Hyperspectral measurements of severity of stripe rust on individual wheat leaves. Eur. J. Plant Pathol. 139, 407-417. Doi: 10.1007/ s10658-014-0397-6

Zhao, D., J.L. Li, and J.G. Oi. 2005. Identification of red and NIR spectral regions and vegetative indices for discrimination of cotton nitrogen stress and growth stage. Comp. Electron. Agric. 48(2), 155-169. Doi: 10.1016/j. compag.2005.03.003 